\title{
ASSESSING ENGLISH STUDENTS VOCABULARY SIZE OF LAMPUNG STATE ISLAMIC UNIVERSITY
}

\author{
Iwan Kurniawan \\ English Education Department, Education Faculty, UIN Raden Intan Lampung \\ J1. Letnan Kolonel H. Endro Suratmin, Sukarame, Kota Bandar Lampung, Lampung 35131, Indonesia \\ Iwan_stain@yahoo.com
}

\begin{abstract}
The aims of this research were to measure the English students' vocabulary size as well to measure the students' vocabulary size which was less and more than 1000 words. The research method that the researcher used was quantitative with 209 students as sample. The research instrument was a test which consisted of 79 items. The research findings show the first year students of UIN Raden Intan English department have an average vocabulary size 1400 words. The number of the first year students of UIN Raden Intan English department who have the vocabulary size less than 1000 words is about 11 students or only $6 \%$ students. On the other hand, the number of students who have the vocabulary more than 1000 words is about 192 students or $94 \%$ students.
\end{abstract}

Keywords: assessing, vocabulary size, English Department students, first year students

\section{INTRODUCTION}

The vocabulary plays an important role in the language learning. It can be seen from the advice that David Wilkins stated that without grammar, it would be very hard to convey, without vocabulary nothing can be conveyed. It means that if the students spend most of the time in learning the grammar, their English will have progress, but it will improve a lot if they start to learn a vocabulary or words (Thornbury, 2002). If the students only have a limited vocabulary, it will be a barrier for them from learning a foreign language (Subekti \& Lawson, 2007). It can be said that the vocabulary is the heart of language.

From these arguments, it cannot be denied that the role of vocabulary is crucial for teaching and learning the language. However, the vocabulary learning has been there for a long time; then it becomes neglected especially in the 1950s and 1960s when Audio-Lingual methodology dominated the teaching methods. It happened because at that time, the language learning focused on the grammar and phonology. The Audio Linguist believed that to learn the language it should be emphasized on the basic grammatical acquisition and after that learn to build large vocabularies. In the 1950s, many linguists argued that the vocabulary was the easiest aspect, so the students would not pay attention in the classroom. Many language teachers attach the vocabulary section as a small part of reading instruction.

On the other hand, in the 1970s and 1980s, the teaching and learning of vocabulary courses have developed well. One of the reasons for its resurgence is the presence of the computer that can provide a large amount of information for words analysis. Besides that, in this period, the teaching concept of the communicative language course triggers the teaching and learning of the vocabulary course and partly the influence of natural approach. The people who believe with this view, agree that at the early stage of language acquisition, the vocabulary comes first and then the grammar. They 
mention that the learner needs to acquire an adequate number of vocabularies to be able in communication.

In addition, the vocabulary acquisition is never slow down by the age, and it is very different compared with the other aspect of the language especially pronunciation. The more mature someone is, the easier for him/her to add the vocabulary. It happens likely because an adult has a lot of knowledge about the world and able to learn new words every day. Nowadays, there is an agreement that the development of adequate vocabulary is essential for the language learning. From these explanations, the notion that the vocabulary plays in the strategic position in language learning is unquestionable, so in the recent years, the teaching of language has been included as the main component. Vocabulary is not treated as the additional material, and the syllabus designers have put it as the basic ability, and that must be acquired at the beginning level.

There is another reason to start learning the language by words. There is an argument from some of the researchers who say that at the beginner level there should be a huge number of productive words, at least 2000 words as the threshold level. If the learner has less than 2000 words, it will be difficult for them to do the listening and speaking part. If they can acquire that number, they can express their idea because those 2000 words are often being used by the native speaker in daily conversation.

Varela (2013) has mentioned that many of the experts agree that high frequency of words is crucial because they include a large number of running words in spoken and written language and they also take place in every language used. He also believes the students who have acquired these words will succeed in daily activities. Even though all languages use many vocabularies, not all these words are used the same. One way to know it is called word frequency. It is how often the word occurs in the normal use of the language. From word frequency, the word "the" is the most frequent in the English language. This word is used about $7 \%$ in every written or oral text. These frequent words are very useful if learners know them; the learners will recognize big proportion of running words in written and spoken English. Most of them are content words and knowing them allows to a good degree of comprehension.

Vocabulary size is the number of words that a person knows. Having a sufficient vocabulary size will ease to master a language, and many scientific investigations show that vocabulary size is a strong indicator of language ability. It is also seen to have the strong correlation with successful efforts in learning language skills such as listening, writing, speaking, and reading. Native speakers' vocabulary sizes generally are measured by words taken from the large dictionary and non-native speakers are estimated through words from frequency list. An educated native speaker will have around 20000 word families. This number is the result of addition 1000 words each year after having 5000 words in the age five years. The most adult non-native speaker is considered lucky to have 5000 word families after learning several years. There has been a formal calculation that a non-native speaker needs 18 years to have the same level of a native learner's word acquisition in one year. It occurs because of the exposure or need than aptitude. Research done in New Zealand indicated that native speakers of English get around a 1000 words family a year after three years old so that in 13 years old, a kid has about 10500 words family. For 17 years old teenager possesses around 14000 or 15000 words family. For non-native speaker of English, he or she is really suggested to have around 1000 words family a year to gain 8000 to 9000 words for reading novels and newspapers.

A person who just travels two weeks to England definitely needs different demand compared to a student who wants to study in England. There is a big question about how many words a learner needs to know that it can function in all situations. A figure that often mentioned is 2000 word families. This number is the words which often used by English native speaker in daily conversation. Knowing this number, a reader can understand nine from ten words in many written text and $80 \%$ words in the text which means one word in every five unfamiliar. However, there are many strong 
arguments say that 2000 is a minimum or threshold level is not enough. Recently, researchers propose number at least 3000 word families. Mastering minimum 3000 word families will support students' success in academic reading at the university level and understand at least $95 \%$ of a text. Besides, to pass a specific test such as Cambridge First Certificate, TOEFL or IELTS, a working vocabulary of 5000 word families are needed (Thornbury, 2002). Undergraduate non-native speaker of nonEuropean countries could study successfully in English speaking countries by having word families around 5000-6000. A non-native speaker can study Ph.D. level well with vocabulary about 9000.

The purpose to test students' vocabulary is to know how effective the teaching is. Without a test, the teachers never know the progress of their students in acquiring English vocabulary that can show the students' learning progress and motivation. A teacher can improve his/her teaching by choosing a better strategy or add more unknown words to be memorized by students. The teacher also can predict students' progress and diagnose weakness in vocabulary learning. A test also has positive backwash that is if the students know that their ability will be measured, they will learn more diligently. The test will push them to see back their vocabularies. The test result also can be a prediction to determine whether or not they are ready for study at the certain level of education such as undergraduate or graduate level in English speaking countries. Moreover, test vocabulary result is also valuable for syllabus designer when planning a course for students. In reading class, syllabus designer can use the research result to decide how the reading program is designed and taught. In higher level, vocabulary size research findings can also be used at college or university admission policy because the vocabulary level that students have will play the important role to adjust with language demands for the study such as reading text books, writing papers, listening lectures and classroom presentation.

In motivating the students to increase their vocabularies and as the description for them to know the meaning of their vocabularies size, Nation (2016) shows three main frequency levels of high frequency, mid frequency, and low-frequency words that can be seen in Table 1.

Table 1 Level of Word Frequency

\begin{tabular}{cc}
\hline Level & $\mathbf{1 0 0 0}$ word family lists \\
\hline High Frequency & $1000-2000$ \\
Mid Frequency & $3000-9000$ \\
Low Frequency & 10000 on \\
\hline
\end{tabular}

There are some kinds of previous research about vocabulary size. Wen-Ta Tseng in 2016 has used computer to measure students vocabulary size with a program that is called Computer Adaptive Testing (CAT). This investigation demonstrates that CAT could classify precisely the test-takers into mastery and non-mastery groups (Tseng, 2016). Another research is done in Turkey toward EFL teachers. Another research is done in Turkey toward EFL teachers. Ozondor(2016) found out that there is no significant correlation between students academic achievement (GPA) and their receptive vocabulary size. According to Senturk (2016), there is still growing the number of experts' wish to estimate EFL vocabulary size. This phenomenon has inspired researcher to conduct a research toward the vocabulary size that possessed by Lampung State Islamic University English Department students, especially for the first semester students. Therefore, some research questions are formulated such as; how many vocabularies sizes do the first semester English Department students have? How many do the first semester English Department students have vocabulary less than 1000 words? And how many do the first semester English Department students have vocabulary more than 1000 words? To answer those questions, the researcher then plans a research in English department of Lampung Islamic State University. 


\section{METHODS}

This research employs quantitative method since it calculates students' vocabulary size. Population in this research is all UIN Raden Intan English department first-year students that consisted of 290 people that are placed in 8 classes. The classes constitute of A, B, C, D, E, F, G and H. However, class $F$ has been used as the try-out class, so this class is not used as the sample. To determine the sample, the researcher uses the table of the sample (Sugiyono, 2011). The table indicates if the number of population is 290 , so the sample is 202 people. This research then uses simple random sampling because the classes are the same. From 8 classes, one class is used as try-out, so the rest is about seven classes that have been taken as the source of the sample. From each class, the researcher takes about 29 students.

The instrument that used in this research is vocabulary test. The test is designed by researcher and is tested to the sample of research. The production of the test is based on the theory of John Read. To set the vocabulary size test based on word frequency, the researcher uses the list of high-frequency words that is the General Service List (GSL) as the basis of sampling that consists of 2000 words. The GSL is developed in 1953 by Michael West. The frequency figures for most items are based on a 5000000 word written corpus.

The production of the test is done by taking $5 \%$ from 2000 words, for example. The researcher chooses randomly 50 words from the first and the second 1000 words of the list, so there are about 100 words as items. If students could choose correct answer 60 from 100 and then multiplied 2000, he or she would get score 1200. It means the student's vocabulary size is 1200 words. After try-out was done on October 7th, 2016, it is found from 100 items only 79 items are valid, and this number was used to test students' vocabulary size. There are two steps of data analysis in this research by know students vocabulary size, the following formula was employed:

$$
\begin{array}{ll} 
& \multicolumn{1}{c}{\mathrm{N}} \\
\mathrm{W}= & \mathrm{I} \\
\mathrm{W} & =\text { Number of word } \\
\mathrm{N} & =\text { Number of Correct answer } \\
\mathrm{H} & =\text { Number of headwords on the list } \\
\mathrm{I} & =\text { Number of test item }
\end{array}
$$

After knowing the vocabulary size, then researcher calculates the percentage of students who got less and more 1000 vocabularies.

\section{RESULTS AND DISCUSSIONS}

Figure 1 shows that average students in class A had 1334 vocabulary size. This number indicates that all students or 29 students had more than 1000 words and no students who had less than 1000 words. According to theory, the meaning of this number that all students in class A can read comprehensively around 75\% of a written English text and understand around 80\% of the spoken text. 


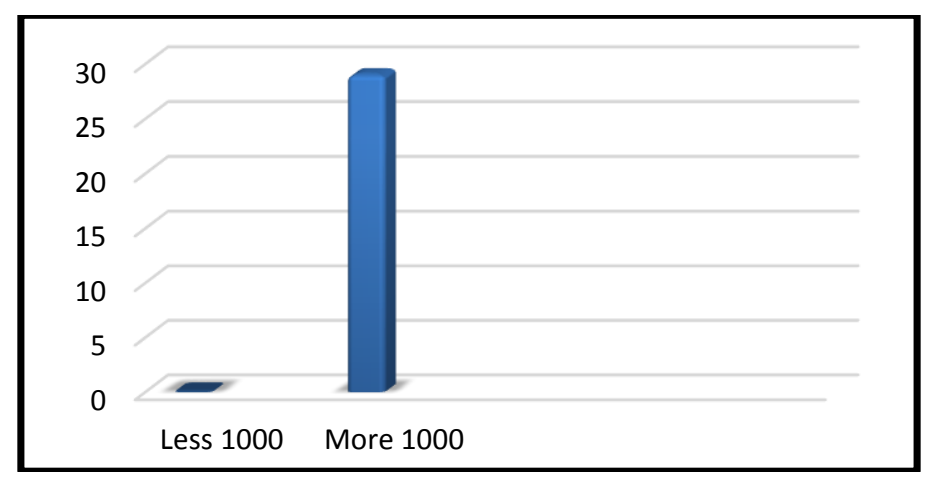

Figure 1 Vocabulary Size of Class A

Figure 2 reveals that average students in class B have 1484 vocabulary size. This number indicates that most students or 28 students have more than 1000 words and only one student who has less than 1000 words. The meaning of this number that majority students in class B can read comprehensively around 75\% of a written English text and understand around 80\% of the spoken text. Only one student who cannot do that.

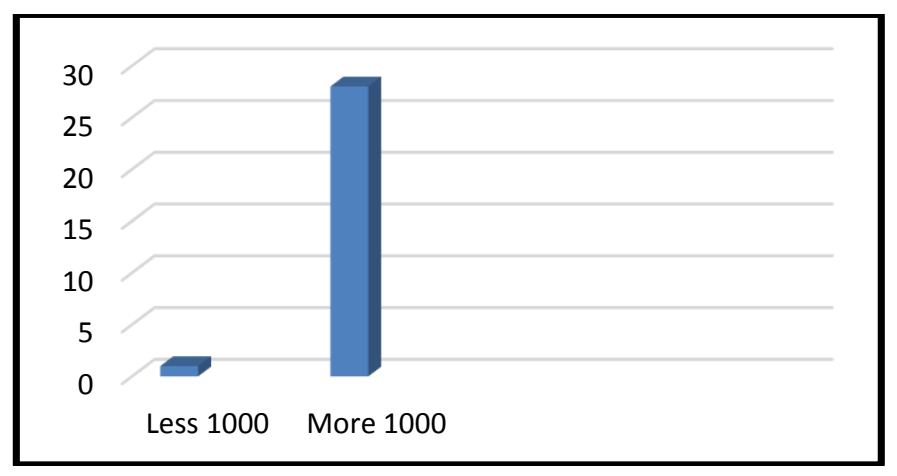

Figure 2 Vocabulary Size of Class B

Figure 3 reports that average students in class $C$ have 1279 vocabulary size. This number tells that there are more students or 25 students who have more than 1000 words. This figure also mentions there are four students who possessed less than 1000 words. The meaning of this number that most students in class B can read comprehensively around $75 \%$ of a written English text and understand around $80 \%$ of spoken text and only a few who cannot do.

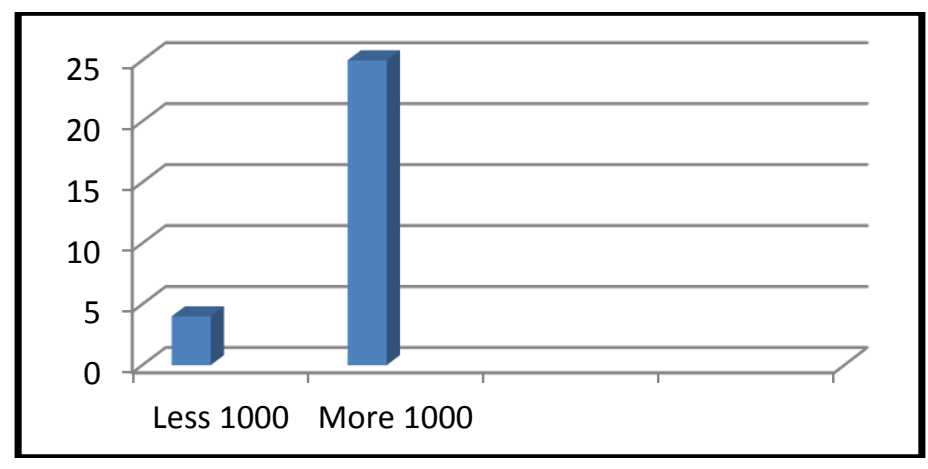

Figure 3 Vocabulary Size of Class C 
Figure 4 shows that average students in class D had 1497 vocabulary. This number tells that there are more students or 27 students who have more than 1000 words and only two students who have less than 1000 words. This number indicates that students in class D can read comprehensively around $75 \%$ of a written English text and understand around $80 \%$ of spoken text and only two students are difficult to do it.

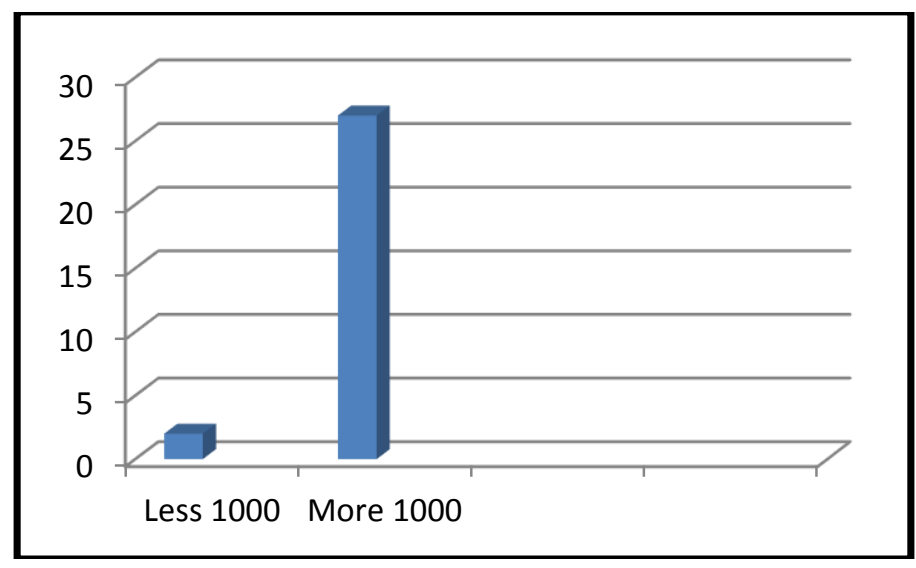

Figure 4 Vocabulary Size of Class D

Based on Figure 5, it can be described that average students in class E have 1510 vocabulary size. This figure also tells that there are 28 students who have vocabulary size more than 1000 words and only one student who has less than 1000 words. The meaning of this finding that majority students in class E can read comprehensively around $75 \%$ of a written English text and understand around 80\% of the spoken text. In contrast, only one person who faces difficulties to read comprehensively.

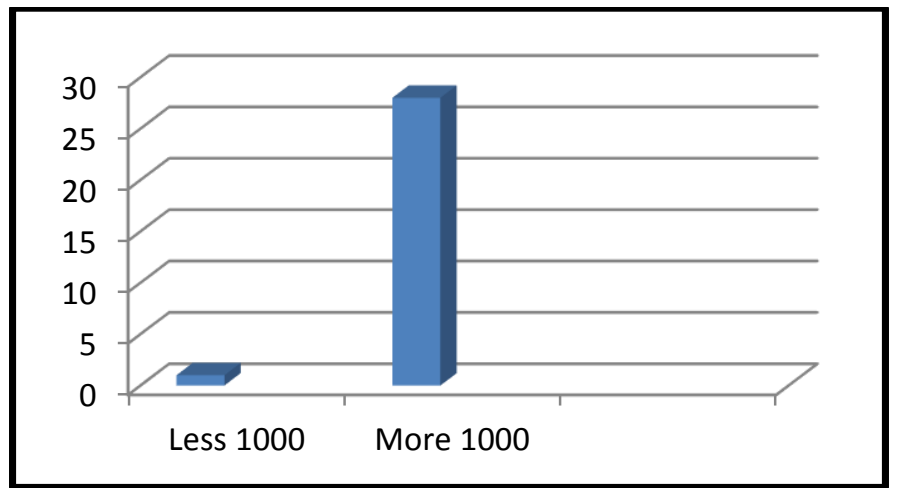

Figure 5 Vocabulary Size of Class E

Figure 6 reports that average students in class $G$ have 1380 vocabulary size. This number tells that there are more students or 27 students who have more than 1000 words. This figure also mentions that there are only two students who possessed less than 1000 words. The meaning of this number that majority students in class G can read comprehensively around $75 \%$ of a written English text and understand around $80 \%$ of spoken text theoretically. 


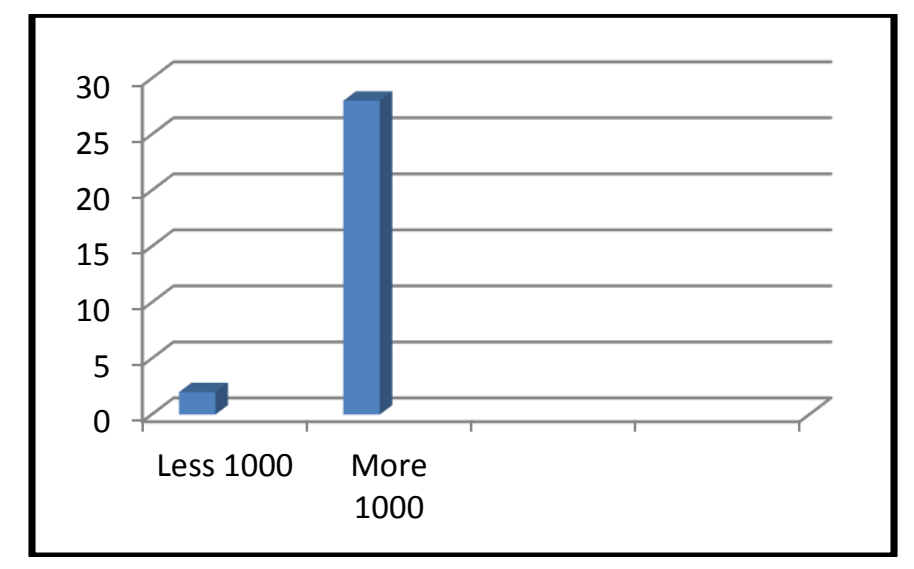

Figure 6 Vocabulary Size of Class G

Based on Figure 7, it can be seen that average students in class $H$ have 1430 vocabulary size. This number indicates that most students or 28 students have more than 1000 words and only one student who has less than 1000 words. The meaning of this number that generally students in class $\mathrm{H}$ can read comprehensively around 75\% of a written English text and understand around $90 \%$ of spoken text and only one who does not.

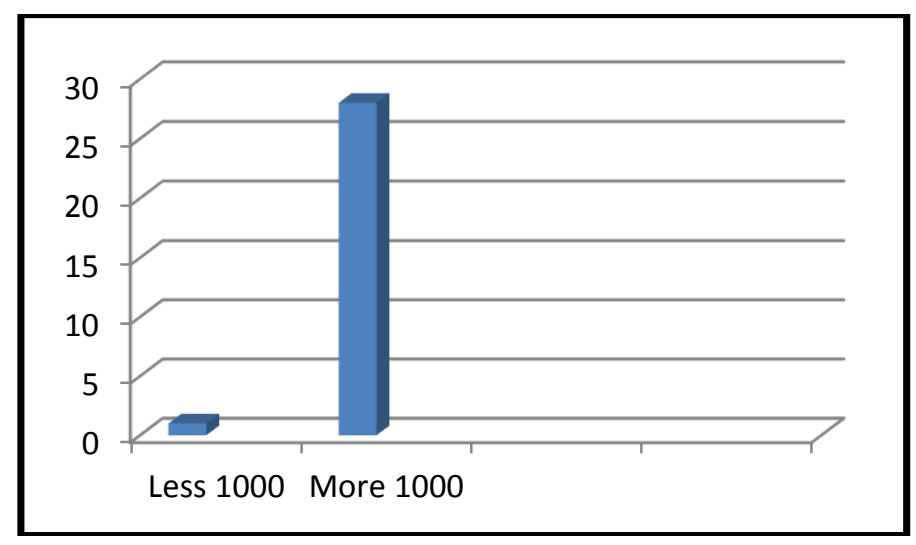

Figure 7 Vocabulary Size of Class H

Form all these explanations, Table 2 shows the number of all the students' vocabulary size.

Table 2 Number of All the Students' Vocabulary Size

\begin{tabular}{ccc}
\hline No & Name of Class & Average of Vocabulary size \\
\hline 1 & Class A & 1334 \\
2 & Class B & 1484 \\
3 & Class C & 1279 \\
4 & Class D & 1497 \\
5 & Class E & 1510 \\
6 & Class G & 1380 \\
7 & Class H & 1430 \\
\hline & $\sum$ score all class & 9914 \\
\hline & $\sum$ Mean
\end{tabular}


While Figure 8 shows the distribution of all the students' vocabulary size.

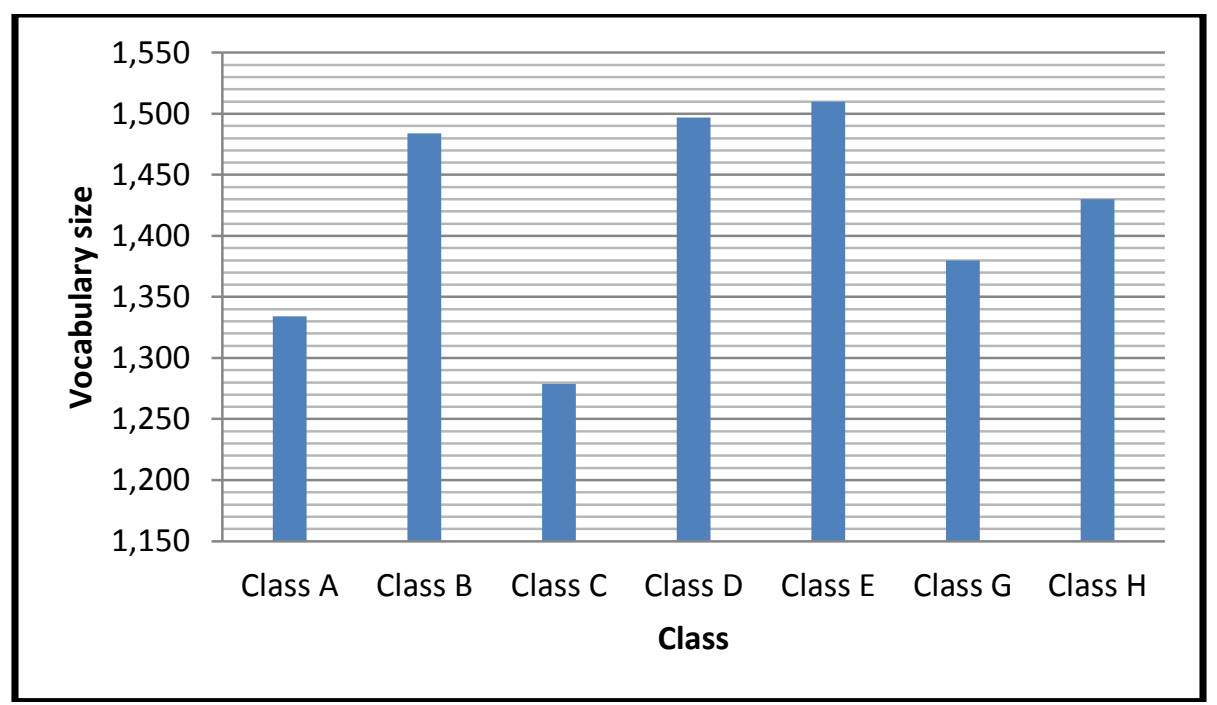

Figure 8 The Distribution of All the Students' Vocabulary Size

Table 2 and Figure 8 reveal the number of each class vocabulary size from class A to class $\mathrm{H}$. All classes have more than 1000 words. Class A has vocabulary size 1334 words, class B has 1484 words, class C has 1279 words, Class D has 1497 words, Class E has 1510 words, class G has 1380 words, and class $\mathrm{H}$ has 1430 words. It also tells the mean score is 1400 words, so that the average students of 1st semester of UIN Raden Intan have 1400 vocabulary sizes. The lowest score belongs to class $\mathrm{C}$ with 1279 words, and the highest score belongs to class $\mathrm{E}$ with 1510 words. Table 3 shows the number of students who are getting less than 1000 words and who are getting more than 1000 words.

Table 3 The Number of the Students who are Getting Less 1000 Words and More 1000 Words

\begin{tabular}{cccc}
\hline \multirow{2}{*}{ No } & \multirow{2}{*}{ Name of Class } & \multicolumn{2}{c}{ Number of Vocabulary Size } \\
\cline { 3 - 4 } & less 1000 words & More 1000 words \\
\hline 1 & $\mathbf{A}$ & - & $\mathbf{2 9}$ \\
2 & $\mathbf{B}$ & $\mathbf{1}$ & $\mathbf{2 8}$ \\
3 & $\mathbf{C}$ & $\mathbf{4}$ & $\mathbf{2 5}$ \\
4 & $\mathbf{D}$ & $\mathbf{2}$ & $\mathbf{2 7}$ \\
5 & $\mathbf{E}$ & $\mathbf{1}$ & $\mathbf{2 8}$ \\
6 & $\mathbf{G}$ & $\mathbf{2}$ & $\mathbf{2 7}$ \\
7 & H & $\mathbf{1}$ & $\mathbf{2 8}$ \\
\hline & Escore all class & $\mathbf{1 1}$ & $\mathbf{1 9 2}$ \\
\hline & $\sum$ Percentage & $\mathbf{6 \%}$ & $\mathbf{9 4 \%}$ \\
\hline
\end{tabular}

The distribution of students who got less and more 1000 words can be also seen in Figure 9. 


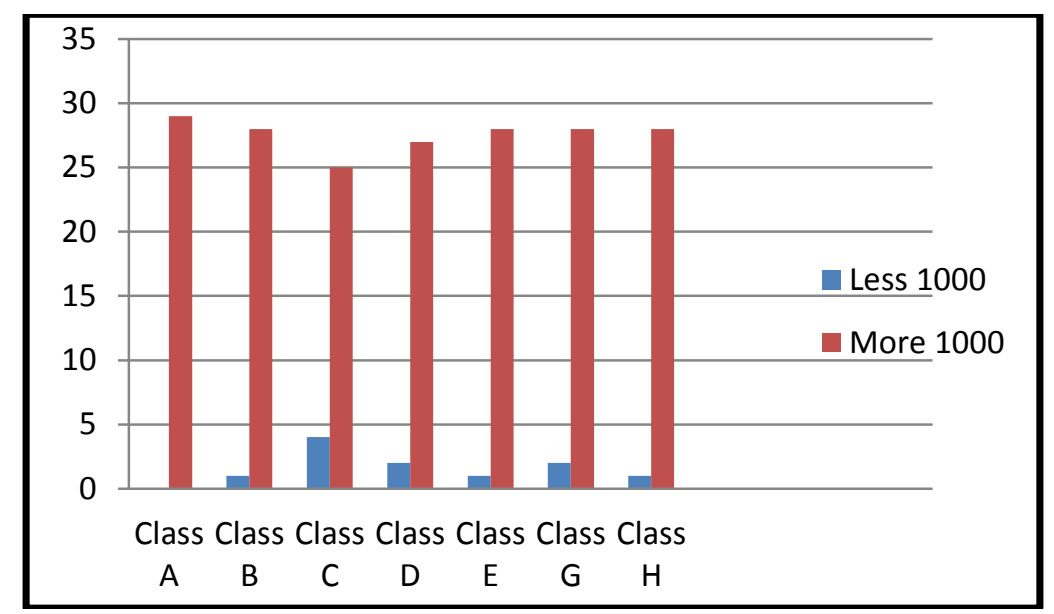

Figure 9 The Distribution of the Students who Get Less and More 1000 Words

Table 3 and Figure 9 show those majority students of the first semester who have more than 1000 words where 192 students or $94 \%$ students include to this category whereas only 11 students or $6 \%$ students who have less than 1000 words. The class that does not have less than 1000 words is class $\mathrm{A}$, and the class that has the least than 1000 words is class C. Class $\mathrm{C}$ has four students with less than 1000 words.

This part discusses the result of students' vocabulary size measurement at the first semester students of UIN Raden Intan English department. The test is conducted to class A, B, C, D, E, G, and $\mathrm{H}$. Class $\mathrm{F}$ is not tested because this class is used as the try-out class to see the validity and reliability of test items. After conducting try-out, it is found that from 100 items; only 79 items are valid, so this number is used to test students vocabulary size. The test is multiple choices with four options. The test uses the bilingual format in which the question is in English, but the answers or options are in the Indonesian Language.

After conducting the test on each class, it is found that class A gets 1334 words, Class B gets 1484 words, Class C gets 1279 , class D gets 1497 , class E gets 1510 , class G gets 1380 , and class $\mathrm{H}$ gets 1430. The total score is 9914 words, and after divided with a number of classes, so it is found 1400 words as the average score of students' vocabulary size. This number is actually higher than former vocabulary size measurements in Indonesia. Two types of research that are done by Nurweni \& Read (1999) mentioned that the average 1200 words have by first-year Indonesia students in Lampung University and Alwasilah (2007) stated that Satya Wacana University's new students are only accompanied by 1000 words. The possible reason which caused the first year UIN English students has the higher score because their backgrounds are from English department that affected their motivation always to learn and add their vocabulary to meet their study demands. By having 1400 words, the first year students of UIN Raden Intan English department are able to comprehend $75 \%$ of written text and around $80 \%$ spoken texts.

Data analysis also shows that there are 11 or $6 \%$ students who have vocabulary less than 1000 words. They are students of class B, C, D, E, G, and H. Only students of class A that do not have such student. Most students have the vocabulary more than 1000 words with 192 or $94 \%$. They exist in class A through $\mathrm{H}$. The students with less than 1000 words would face difficulties to understand both written and spoken texts whereas students with more than 1000 words would have good enough abilities to understand both written and spoken texts. However, this number is not ideal since the good one is about 2000 words. The findings of this research could be reflections of many parties. For vocabulary lecturers, they can improve their teachings by choosing better strategies or add more 
unfamiliar words for students to be learned. For students, they can predict their strength and weakness in learning vocabularies, and they can seek better strategies in learning new words. For syllabus designer, they can use the result results to decide what material to be taught, and what teaching strategies to be employed when designing the new syllabus.

\section{CONCLUSIONS}

Based on the findings and discussions, the researcher has drawn some conclusions as follows to answer research objectives in the introduction. The first year students of UIN Raden Intan English department have average vocabulary size 1400 words. The number of the first year students of UIN Raden Intan English department who have vocabulary size less than 1000 words is about 11 students or only $6 \%$ students. The number of the first year students of UIN Raden Intan English department who have vocabulary size more than 1000 words is about 192 students or $94 \%$ students.

\section{REFERENCES}

Alwasilah, C. (2007). Language, Culture, Education: A portrait of Contemporary Indonesia. Bandung: Andira.

Nation, P. (2016). The Vocabulary Test. Retrieved from www.uvictoria.c.nz/.../vocabulary_size test_Information.

Nurweni, A., \& Read, J. (1999). The English Vocabulary Knowledge of Indonesian university students. Journal of English for Specific Purpose, 18(2), 161-175. https://doi.org/10.1016/S0889-4906(98)00005-2.

Ozondor, O. (2016). Student EFL Teachers' Receptive Vocabulary Size. Journal of Procedia-Social and Behavioral Sciences, 232, 444-450. https://doi.org/Doi:10.1016/j.sbspro.2016.10.061.

Subekti, N., \& Lawson, M. J. (2007). Vocabulary acquisition strategies of Indonesia postgraduate students through reading. Journal of International Education, 8(2), 485-496.

Senturk, B. (2016). Self-regulation Strategies and Vocabulary Size of EFL Turkish University Students. Journal of Procedia-Social and Behavioral Sciences, 232, 90-97. https://doi.org/Doi:10.1016/j.sbspro.2016.10.023.

Sugiyono. (2011). Metode Penelitian Kuantitatif, kualitatif, dan RD. Bandung: Alfabeta.

Thornbury, S. (2002). How to teach Vocabulary. Essex: Pearson Education Limited.

Tseng, W. T. (2016). Measuring English vocabulary size via computerized adaptive testing. Computers \& Education, 97, 69-85. https://doi.org/10.1016/j.compedu.2016.02.018.

Varela, M. L. R. (2013). High Frequency English words in spoken learner language:actual, career and pretend as a case in point. Journal of Procedia-Social and Behavioral Sciences, 95, 90-97. https://doi.org/10.1016/j.sbspro.2013.10.682. 